\title{
The Effects of Knowledge, Training, and Competency on the Performance: A Case of Local Public Agricultural Mentors
}

\section{Erni Saptiowati S.}

Faculty of Economics, Universitas Terbuka, Indonesia

Email: ersaptiowati@gmail.com

\begin{abstract}
:
This research aimed to analyze the effects of knowledge, training, and competency on the performance, which local public agricultural mentors/officers in the Yapen Islands Regency are the unit analysis. Of 100 respondents were used as the saturated sample in this research. The research applied a survey method and used a five-point Likert scale as the instrument and the statistics program SPSS to analyze data. The analysis methods included descriptive analysis, validity and reliability tests, classical assumption test, and regression analysis. The research results show that the variables knowledge, training, and competency had significant positive effects on local public agricultural mentors' performance at the Yapen Islands Regency.
\end{abstract}

\section{Keywords:}

knowledge; training; competency; outreach workers

\section{Introduction}

Human resources development in the agricultural sector is essential, given that human resources are among the critical factors in economic reform (Buntuang \& Adda, 2018; Martapina \& Warokka, 2018). It aims to create human resources of high quality, skilled, and highly competitive in global competition, which has thus far been neglected (Tayibnapis et al., 2018). Concerning this, attention should be directed toward two chief factors about agriculture, human resources in rural settings, namely agricultural officers/mentors and farmers (Kristiana \& Hasan, 2015). The two groups of human resources are actors and implementers who drive the success of agricultural development programs.

Among agriculture-related officers is a functional group of agricultural field mentors (PPL) (Ali et al., 2012). Agricultural field mentors conduct coaching and direct liaison or interaction with farmers (Purnomo \& Lee, 2010). The primary coaching task is intended to improve the quality of human resources in the agricultural field. To exercise this task, agricultural field mentors must be reliable, independent at work, professional, and with global perspectives (Benu \& Wangke, 2016). Stakeholders (the Indonesian Ministry of Agriculture and local government) have continuously improved human resources quality in the agricultural field (Winoto \& Siregar, 2016). Development in the agricultural sector encompasses improving farmer quality through extended-educational agricultural programs (Margono \& Sugimoto, 2011).

Field agricultural mentors/officers are agents of change directly associated with agricultural affairs (Pelealu et al., 2018). The primary function of field agricultural mentors/officers is to modify farmers' behaviors through non-formal education to allow them to live on a sustainable basis (Anderson \& Feder, 2007). According to Sapoetra (1994), field agricultural mentors/officers are in charge of encouraging farmers to change their mindsets, ways of working, and ways of living to better fit the current development in agricultural technologies. He says that the field agricultural mentors/officers influence their targets 


\section{Britain International of Humanities and Social Sciences (BIoHS) Journal \\ ISSN: 2685-3868(Online), 2685-1989(Print) \\ Vol. 3, No. 1, February 2021, Page: 144-158}

(farmers) through their role as a motivator, educator, dynamist, organizer, communicator, or adviser (Sapoetra, 1994).

The conditions of agriculture-related educational programs that underwent continuous changes since the New Order Era through the Reform Era have a role in influencing the educational program's image in the agricultural sector (Pratomo \& Warokka, 2013). To organize local agricultural educational program activities, the government made some policies through some governmental regulations. First, the Letter of Joint Decision of the Minister of Home Affairs and the Minister of Agriculture No. 539/KPTS/LP.120/4/1996, subsequently, No. 54 of 1996 on the Implementation of Agricultural Mentorship Activities, and finally, followed by the issuance of the Letter of Decision of the Minister of Home Affairs No. 35 of 1996 on the Guide to the Establishment of the Organization and the Governance of the Center for Agricultural Information and Mentorship. These policies are expected to smoothen agricultural mentorship programs, especially in the Yapen Islands Regency.

The fact in the field indicates that the implementation of agricultural mentorship activities in the Yapen Islands Regency still falls short of expectations and has yet to reach an optimum level. The performance of field agricultural mentors/officers ever since the return of mentorship activity authority to the local government continuously fell. There tends to be a lack of regeneration of sufficiently competent field agricultural mentors/officers. The decline of performance among local field agricultural mentors/officers can be seen from the data in the 2018-2019 Performance Accountability Reports of Yapen Islands Regency. The report shows that the field agricultural mentors/officers empowerment programs that were indicated to be with improvement made up only $65.66 \%$ of the targeted $100 \%$. Besides, starting from 2018 , the achievement has been down with a realized rate of $85 \%$.

The low performance of field agricultural mentors/officers, based on the interview results with the head of the department of human resources of the Yapen Islands Regency, was due to the poor implementation of the Laku Susi (i.e., training, visitation, and supervision) work system. Its poor implementations are a result of the discontinuance of training or education for field agricultural mentors/officers, affecting the knowledge, attitudes, and skills of the mentors/officers themselves, and of the lack of awareness of responsibility. The field agricultural mentors/officers' knowledge development is critical and can be made possible through training in which the mentors/officers participate (Lubell et al., 2014). The mentors/officers' participation in the training will automatically improve their competencies. As stated by Palumbo et al. (2005), employee performance can be fostered by improving employee knowledge.

Knowledge is a collection of information acquired through experience or from birth that makes someone know about something (Reber, 2010). It is posited by Almusaddar et al. (2018) that job knowledge is an essential factor in determining the work eligibility for a given job in an organization. Individuals improve their performance by improving the various knowledge and experiences at their disposal (Kohansal et al., 2013). Knowledge can be acquired through training. Hence, training is also considered paramount in employee performance improvement. Notoadmojo (2012) states that training is an effort to develop human resources, especially in enhancing intellectual abilities and personality, to improve their performance. Therefore, providing training for employees constitutes one of many ways of improving their performance (Cooke, 2001). 
The frequency of training provided for the field agricultural mentors/officers of the Yapen Islands Regency was still low due to the minimal budget allocation for field agricultural mentors/officers' training, which eventually resulted in low competency levels (Abdiyanto \& Warokka, 2015). From the interviews with some field agricultural mentors/officers in the Yapen Islands Regency, it was revealed that it was thanks to the training provided to acquire new knowledge. They could share with the farmers under their guidance. However, over the past few years, training had no longer been provided on the grounds of minimum budget allocation for field agricultural mentors/officers' training.

Aside from knowledge and training, competency is also imperative in every human resources process, particularly in improving human resources performance (Kulkarni, 2013). As described by Heriyanto et al. (2018), competency refers to knowledge, skills, abilities, and other things related to high performance at work, such as problem-solving, analytical thinking, or leadership. Employees must have high competencies in order to be able to respond to changes in the environment and thus improve performance (Sabuhari et al., 2020).

Based on the employee performance issue at the Yapen Islands Regency described above, and based on the research gap, it became an interest to investigate the effects of knowledge, training, and competency on the field agricultural mentors/officers' performance in the local government context. Therefore this research aimed to study and analyze the effects of knowledge, training, and competency on the performance of field agricultural mentors/officers at the Yapen Islands Regency

\section{Review of Literatures}

\subsection{Performance}

Performance is an overview of the level of achievement of an activity program or a policy implementation in realizing the targets, goals, vision, and missions of an organization as expressed in the organization's strategic plan (Moeheriono, 2012). Employee performance is defined as the qualitative and quantitative work achievement expected of an employee (Rahman et al., 2015). A higher level of performance reflects an improvement in the efficiency, effectiveness, or quality of completing a series of tasks assigned to an individual in an organization. Employee performance's terminology is concerned with an employee completing the tasks and goals in compliance with the standards set by his/her organization and by him-/herself. His/her performance compares to the performance standard that has been set (Chen et al., 2004). Performance is the estuary and organizational culture is the base, while work motivation, job satisfaction is between the beginning and end (Arif et al, 2019). Performance is about doing work and the results achieved from the job. Performance is about what is done and how to do it. Performance is the result of work that has a strong relationship with the organization's strategic goals, customer satisfaction and economic contribution (Wibowo in Saragih and Ananda, 2019).

\subsection{Knowledge}

Knowledge is the result of human sensing or the result of human knowledge of an object through his/her sensing faculties such as sight, smell, and hearing, among others (Notoatmodjo, 2003). It is posited by Almusaddar et al. (2018) that job knowledge is an essential factor in determining the work eligibility for a given job in an organization. A company that allows its employees sound knowledge management will improve its performance (Nuryanti et al., 2018). 
Knowledge in work is useful in staffing, recruitment, placement, training, and development in various organizations (Kuvaas et al., 2016). According to Kohansal et al. (2013), individual performance improvement can be done by sharing knowledge and experience. Knowledge sharing can be performed to the extent to which the organization shares knowledge resources within operational boundaries (Liao et al., 2011). As conveyed by Palumbo et al. (2005), knowledge contributes a more significant variance in performance improvement. The research by Kohansal et al. (2013), Nuryanti et al. (2018), and Payal et al. (2019) found that knowledge was positively related to performance. Therefore, referring to previous empirical findings, the first hypothesis to be proposed is as follows:

H1: Knowledge has a significant positive effect on the performance of field agricultural mentors/officers.

\subsection{Training}

Training is a short-term educational process that uses a systematic, organized procedure to allow workers to pursue knowledge and technical skills for a specific purpose. According to Athar and Shah (2015), employee training plays a prominent role as it increases organizational efficiency and helps employees increase their performance efficiently. The training aims to improve organizational effectiveness and to exert influence on employee performance, and, concerning it, organizational performance through the mediation of employee performance (Shaheen et al., 2013).

Efficiency and effectiveness are ingredients of performance, in addition to competitiveness and productivity, and training is one way to improving individual performance (Cooke, 2001). In organizational development, training assumes a vital role in improving performance and productivity, eventually placing the organization in the best position in the face of competition and keeping it at the pinnacle (Sultana et al., 2012). Previous research by Athar and Shah (2015), Jagero et al. (2012), Nkosi (2015), and Onyango and Wanyoike (2014) found a significant positive relationship between training and performance. Therefore, referring to previous empirical findings, the second hypothesis to be proposed is as follows:

H2: Training has a significant positive effect on the performance of field agricultural mentors/officers.

\subsection{Competency}

Performance improvement involves various things, one of which is competency (Makawi et al., 2015; Rante \& Warokka, 2016). The competency, or competence, literally means proficiency, ability, and authority. However, by definition, it means the behavioral dimension of individual expertise or superiority with good skills, knowledge, and other behaviors (Echols \& Shadily, 2007). Abomaleh and Zahari (2014) state that, in the public sector, personnel of quality will improve the quality of public services, giving the impression that the government would continually improve the quality of its public services and allow a decent life for the community.

When it comes down to field agricultural mentors/officers, Sumardjo (2008) opines that field mentors/officers' competency is the characteristic attached to a mentor/officer that determines his/her performance effectiveness in assuming the field agricultural mentorship missions. Employees must have high competencies in order to be able to respond to changes in the environment and thus improve performance (Arafat et al., 2012; Sabuhari et al., 2020). The higher the employee competency is, the higher the organizational performance is, and the lower the employee competency is, the lower the organizational performance is (Suharno \& Despinur, 2017; Rizan et al., 2020). Previous research by Martini et al. (2018), Sabuhari et al. 
(2020), and Sarboini et al. (2018) found that competency had a significant positive effect on performance. Therefore, referring to previous empirical findings, the third hypothesis to be proposed is as follows:

H3: Competency has a significant positive effect on the performance of field agricultural mentors/officers.

The three hypotheses proposed are then summarized in the following research model:

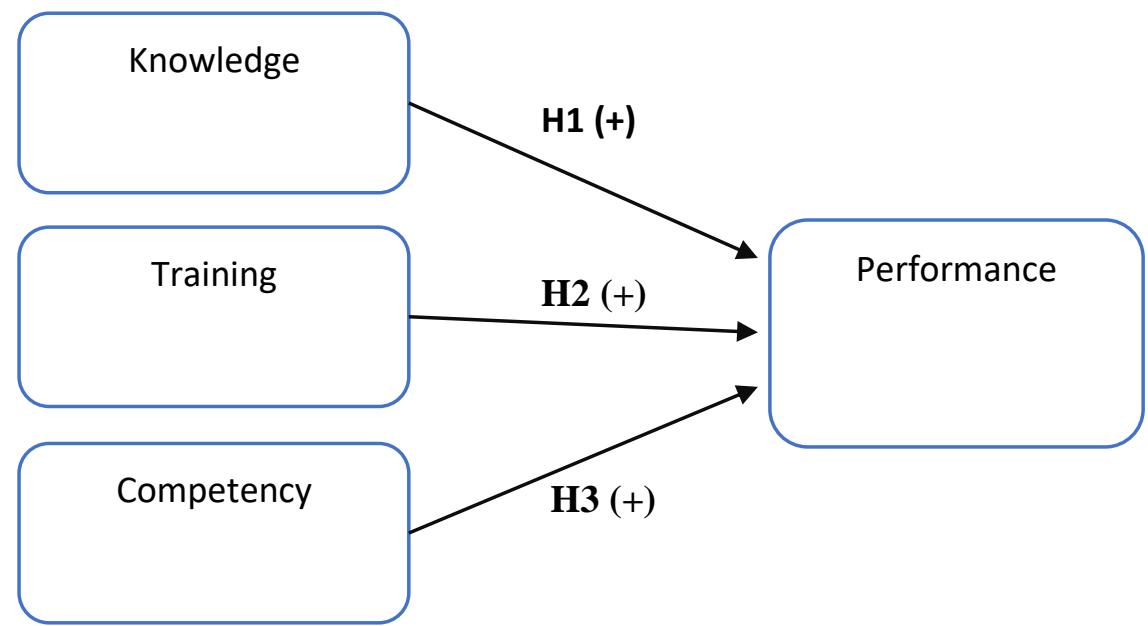

Figure 1. Research Model

\section{Research Methods}

This research is a quantitative study focusing on the objective measurement of a social phenomenon. The saturation sampling technique was used to determine the sample to be enrolled in this research. Saturation sampling is a sampling technique that is used when all members of a population are used as a sample; the whole population is used as a sample under the consideration that all the members are reachable and eligible to be enrolled as respondents. The sample size in this research was 100. The research instrument used was a questionnaire. The respondents' perceptions were gauged with a Likert scale, with scores detailed as follows: $1=$ strongly disagree (SD); $2=$ disagree $(\mathrm{D}) ; 3=$ fairly agree $(\mathrm{FA}) ; 4=$ agree (A); and $5=$ strongly agree $(\mathrm{SA})$. The dependent variables in this research were field agricultural mentors/officers' performance, while the independent variables were knowledge, training, and competency. The statistics program SPSS was used to analyze data. The analysis methods used included descriptive analysis, validity and reliability tests, classical assumption test, and regression analysis that was used to test the hypotheses.

\section{Results and Discussion}

The respondents in this research consisted of 100 field agricultural mentors/officers of the Yapen Islands Regency. The respondents' characteristics are as follows:

Table 1. Respondents' Characteristics Description

\begin{tabular}{cccc}
\hline Categories & Answer Alternatives & Number of Respondents & Percentages (\%) \\
\hline \multirow{2}{*}{ Gender } & Male & 64 & $64 \%$ \\
& Female & 36 & $36 \%$ \\
\hline \multirow{2}{*}{ Age } & $20-30$ Years Old & 25 & $25 \%$ \\
& $31-40$ Years Old & 39 & $39 \%$
\end{tabular}




\begin{tabular}{cccc} 
& $41-50$ Years Old & 27 & $27 \%$ \\
& $>51$ Years Old & 6 & $6 \%$ \\
\hline \multirow{3}{*}{ Latest Education } & Undergraduate & 16 & $16 \%$ \\
Level & D4 - Associate Degree & 37 & $37 \%$ \\
& College & 9 & $9 \%$ \\
& Senior High School & 38 & $38 \%$ \\
\hline \multirow{3}{*}{ Title/Class } & Class II & 43 & $43 \%$ \\
& Class III & 45 & $45 \%$ \\
& Class IV & 12 & $12 \%$ \\
& $<5$ Years & 13 & $13 \%$ \\
Work Experience & $6-10$ Years & 18 & $18 \%$ \\
& $11-15$ Years & 25 & $25 \%$ \\
& $16-20$ Years & 12 & $12 \%$ \\
& $21-25$ Years & 22 & $22 \%$ \\
& $>26$ Years & 10 & $10 \%$ \\
\hline
\end{tabular}

The results above show that the majority of the respondents were male (64\%), aged 31 to 40 years old (39\%), and having the latest education at the senior/vocation high school level $(38 \%)$. The respondents mostly belonged to class III (45\%) and had 11-15 years of work experience $(25 \%)$.

The conditions and characteristics of the respondents' answers were then described via a descriptive analysis. The results of the analysis were to be used to figure out the tendency of the respondents' answers for each variable studied. The respondents' answers were then subjected to categorization in an interval calculated by dividing by five the deduction of the minimum score from the maximum score. The interval obtained was 0.80 . With an interval of 0.80 , the categorization system was as follows: 1.00-1.80 (very low); 1.81-2.60 (low); 2.613.40 (fair); 3.41-4.20 (high); and 4.21-5.00 (very high) (Sugiyono, 2013).

Table 2. Respondents' Responses Recapitulation

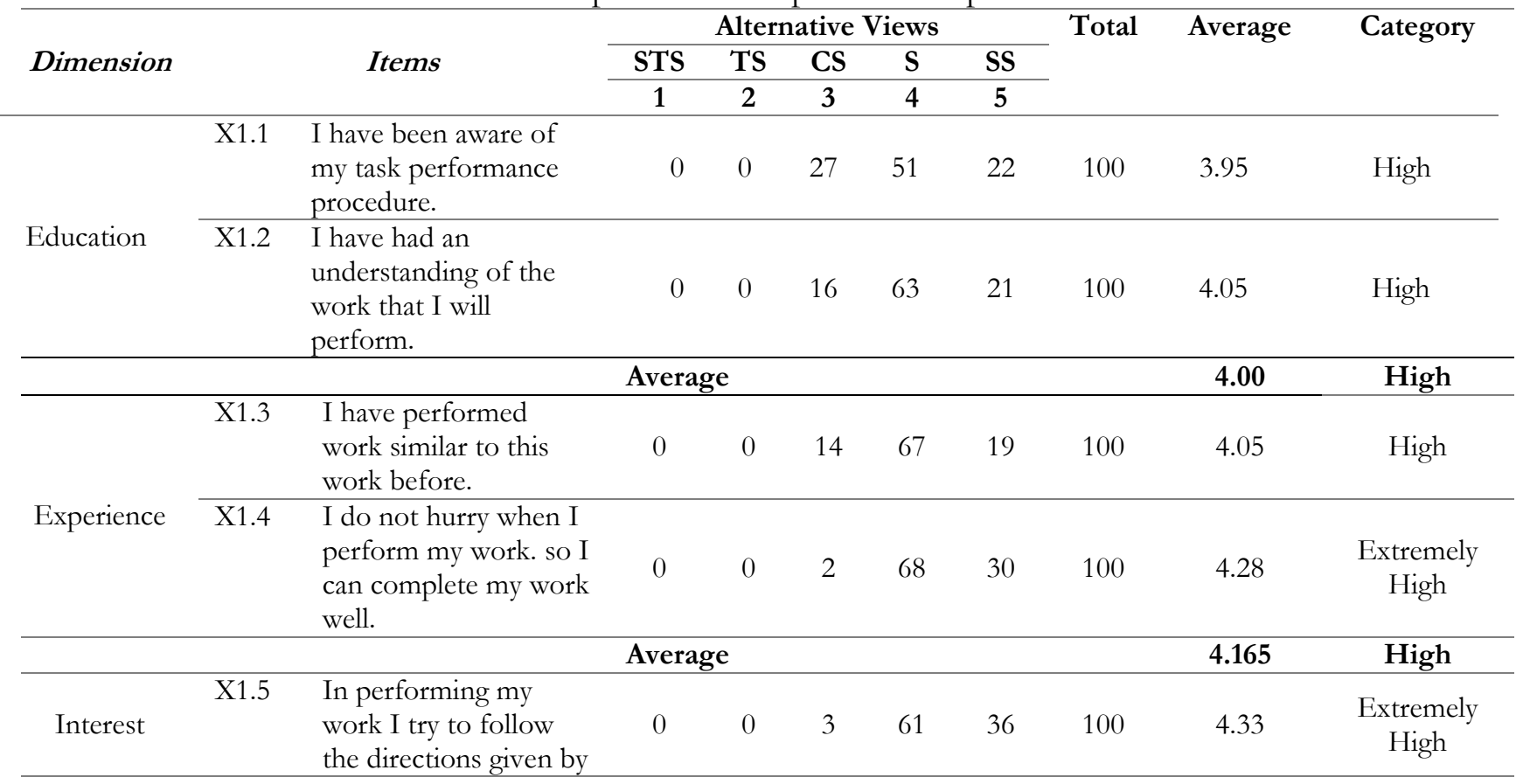




\begin{tabular}{|c|c|c|c|c|c|c|c|c|c|c|}
\hline & & my team leader. & & & & & & & & \\
\hline & $\mathrm{X} 1.6$ & $\begin{array}{l}\text { I try to be present } \\
\text { according to the } \\
\text { schedule that has been } \\
\text { set. }\end{array}$ & 0 & 0 & 4 & 65 & 31 & 100 & 4.27 & Sangat Tingi \\
\hline & & & Ave & & & & & & 4.30 & $\begin{array}{c}\text { Extremely } \\
\text { High }\end{array}$ \\
\hline \multirow{3}{*}{ Instructor } & $\mathrm{X} 2.1$ & $\begin{array}{l}\text { Over the course of the } \\
\text { training, the instructor } \\
\text { exhibited a mastery of } \\
\text { the material delivered. }\end{array}$ & 0 & 0 & 10 & 75 & 15 & 100 & 4.05 & High \\
\hline & $\mathrm{X} 2.2$ & $\begin{array}{l}\text { The instructor had the } \\
\text { ability to deliver the } \\
\text { material. so the } \\
\text { participants gained an } \\
\text { understanding of the } \\
\text { material delivered. }\end{array}$ & 0 & 0 & 10 & 61 & 29 & 100 & 4.19 & High \\
\hline & \multicolumn{8}{|c|}{ Average } & 4.12 & High \\
\hline \multirow{3}{*}{ Participants } & $\mathrm{X} 2.3$ & $\begin{array}{l}\text { I was passionate about } \\
\text { participating in the } \\
\text { training. }\end{array}$ & 0 & 0 & 4 & 35 & 61 & 100 & 4.57 & $\begin{array}{c}\text { Extremely } \\
\text { High }\end{array}$ \\
\hline & $\mathrm{X} 2.4$ & $\begin{array}{l}\text { I had an } \\
\text { understanding of what } \\
\text { was delivered by the } \\
\text { instructor. }\end{array}$ & 0 & 0 & 13 & 70 & 17 & 100 & 4.04 & High \\
\hline & \multicolumn{8}{|c|}{ Average } & 4.305 & $\begin{array}{c}\text { Extremely } \\
\text { High }\end{array}$ \\
\hline \multirow{3}{*}{ Material } & $\mathrm{X} 2.5$ & $\begin{array}{l}\text { The training material } \\
\text { delivered was } \\
\text { appropriate with the } \\
\text { goal of my work. }\end{array}$ & 0 & 1 & 19 & 74 & 6 & 100 & 3.85 & High \\
\hline & $\mathrm{X} 2.6$ & $\begin{array}{l}\text { In this training, an } \\
\text { emphasis was placed } \\
\text { more on the practice } \\
\text { than on the theory. }\end{array}$ & 0 & 0 & 3 & 25 & 72 & 100 & 4.69 & $\begin{array}{c}\text { Extremely } \\
\text { High }\end{array}$ \\
\hline & \multicolumn{8}{|c|}{ Average } & 4.27 & $\begin{array}{c}\text { Extremely } \\
\text { High }\end{array}$ \\
\hline \multirow{3}{*}{ Purpose } & $\mathrm{X} 2.7$ & $\begin{array}{l}\text { I feel that my skills } \\
\text { have been improved } \\
\text { after I participated in } \\
\text { this training. }\end{array}$ & 0 & 0 & 7 & 52 & 41 & 100 & 4.34 & $\begin{array}{c}\text { Extremely } \\
\text { High }\end{array}$ \\
\hline & $\mathrm{X} 2.8$ & $\begin{array}{l}\text { After my participation } \\
\text { in the training. I } \\
\text { become better able to } \\
\text { complete my work } \\
\text { faster and with greater } \\
\text { ease. }\end{array}$ & 0 & 0 & 14 & 69 & 17 & 100 & 4.03 & High \\
\hline & \multicolumn{8}{|c|}{ Average } & 4.185 & High \\
\hline \multirow{3}{*}{ Motivation } & X3.1 & $\begin{array}{l}\text { The mentor/officer } \\
\text { was able to guide the } \\
\text { team to achieve the } \\
\text { team goals. }\end{array}$ & 0 & 0 & 21 & 42 & 37 & 100 & 4.16 & High \\
\hline & X3.2 & $\begin{array}{l}\text { In performing his/her } \\
\text { tasks. The } \\
\text { mentor/officer is } \\
\text { motivated at work at } \\
\text { all times. }\end{array}$ & 0 & 0 & 20 & 46 & 34 & 100 & 4.14 & High \\
\hline & & \multicolumn{7}{|c|}{ Average } & 4.15 & High \\
\hline
\end{tabular}




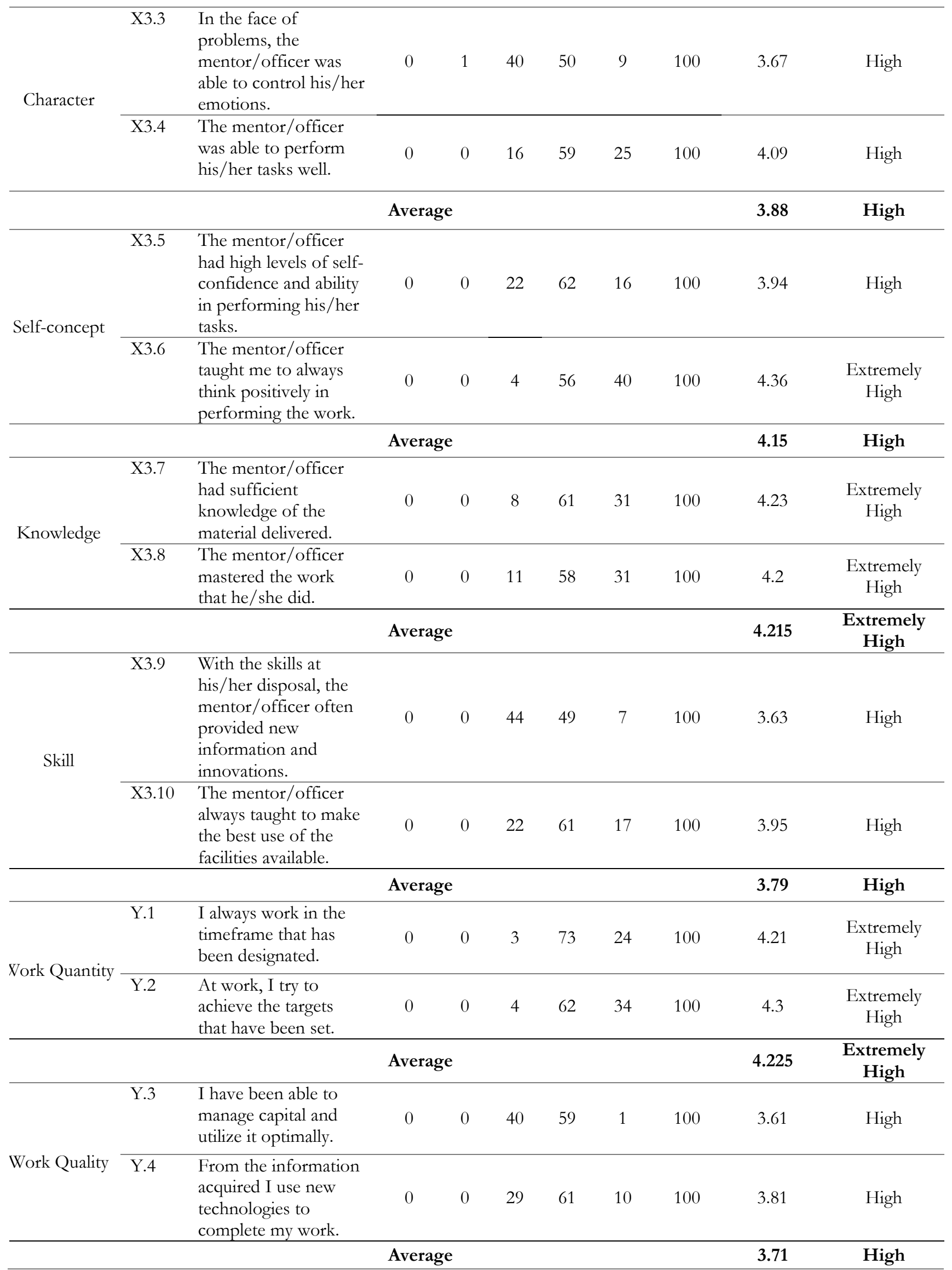




\begin{tabular}{|c|c|c|c|c|c|c|c|c|c|c|}
\hline \multirow{2}{*}{ Collaboration } & Y.5 & $\begin{array}{l}\text { I have exercised and } \\
\text { fulfilled the agreement } \\
\text { that has been agreed } \\
\text { upon. }\end{array}$ & 0 & 0 & 2 & 77 & 21 & 100 & 4.19 & High \\
\hline & Y.6 & $\begin{array}{l}\text { I am able to establish } \\
\text { cooperation and } \\
\text { cohesiveness with my } \\
\text { team members. }\end{array}$ & 0 & 0 & 0 & 28 & 72 & 100 & 4.72 & $\begin{array}{c}\text { Extremely } \\
\text { High }\end{array}$ \\
\hline & \multicolumn{8}{|c|}{ Average } & 4.455 & $\begin{array}{c}\text { Extremely } \\
\text { High }\end{array}$ \\
\hline \multirow[t]{3}{*}{ Initiative } & Y.7 & $\begin{array}{l}\text { I have been able to } \\
\text { make decisions related } \\
\text { to the performance of } \\
\text { my work. }\end{array}$ & 0 & 0 & 14 & 76 & 10 & 100 & 3.96 & High \\
\hline & Y.8 & $\begin{array}{l}\text { I will always try to } \\
\text { improve my } \\
\text { performance. }\end{array}$ & 0 & 0 & 0 & 18 & 82 & 100 & 4.82 & $\begin{array}{c}\text { Extremely } \\
\text { High }\end{array}$ \\
\hline & \multicolumn{8}{|c|}{ Average } & 4.39 & $\begin{array}{c}\text { Extremely } \\
\text { High }\end{array}$ \\
\hline
\end{tabular}

Note: SD = Strongly Disagree; $\mathrm{D}=$ Disagree; FA = Fairly Agree; $\mathrm{A}=$ Agree; $\mathrm{SA}=$ Strongly Agree; $\mathrm{X} 1$ = Knowledge; $\mathrm{X} 2$ = Training; $\mathrm{X} 3$ = Competency; $\mathrm{Y}=$ Outreach Worker Performance.

The mean score generated in each dimension fell in either the "high" or "very high" category. Based on the distribution data, it can be said that the knowledge, training, and competency of outreach workers at the Agriculture and Food Security Office of the Yapen Islands Regency were good.

Table 3. Results of Validity and Reliability Tests

\begin{tabular}{llc}
\hline Item & R Cal & Cronbach's Alpha \\
\hline X1.1 & 0.721 & \\
X1.2 & 0.771 & 0.835 \\
X1.3 & 0.673 & \\
X1.4 & 0.661 & \\
X1.5 & 0.822 & \\
X1.6 & 0.832 & \\
\hline X2.1 & 0.434 & \\
X2.2 & 0.322 & \\
X2.3 & 0.407 & \\
X2.4 & 0.486 & \\
X2.5 & 0.394 & \\
X2.6 & 0.429 & \\
X2.7 & 0.417 & \\
X2.8 & 0.440 & \\
X3.1 & 0.781 & \\
X3.2 & 0.723 & \\
X3.3 & 0.778 & \\
X3.4 & 0.700 & \\
X3.5 & 0.668 & \\
X3.6 & 0.741 & \\
X3.7 & 0.710 & \\
X3.8 & 0.684 & \\
X3.9 & 0.716 & \\
X3.10 & 0.607 & \\
\hline Y.1 & 0.557 & \\
Y.2 & 0.636 & \\
& & \\
\hline
\end{tabular}




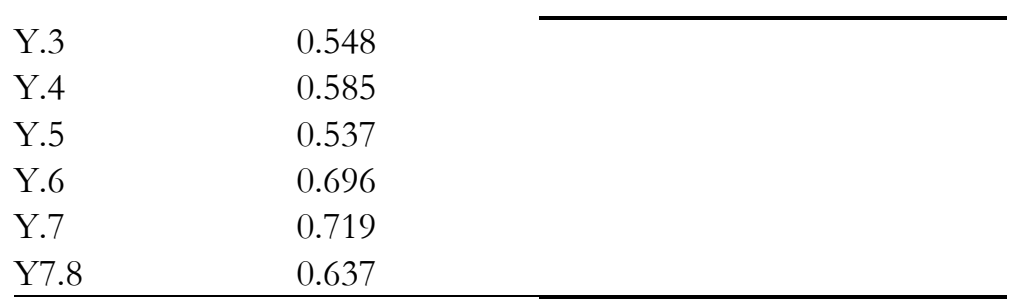

The researchers conducted a validity test to determine whether or not the statements/questions in the questionnaire were valid. The measurement used the productmoment formula taking into account the r-statistic. The results show that all the statements had r-statistic values more significant than the t-table of 0.1435 . Therefore, all the statements were declared valid. Also, a reliability test was conducted based on Cronbach's alpha. The results show that all the variables had Cronbach's alpha values greater than 0.60. Therefore, all the variables were declared reliable.

Table 4. Results of Classical Assumption Test

\begin{tabular}{|c|c|c|c|c|c|c|}
\hline \multicolumn{2}{|c|}{ Normality Test } & \multirow[b]{2}{*}{ Variable } & \multicolumn{2}{|c|}{ Multicollinearity Test } & \multicolumn{2}{|c|}{$\begin{array}{c}\text { Heteroscedasticity } \\
\text { Test }\end{array}$} \\
\hline Kolmogorov Smirnov & $\begin{array}{l}\text { Asymp. } \\
\text { Sig }\end{array}$ & & Tolerance & VIF & Sig Value & $\begin{array}{c}\text { Sig } \\
\text { Limit }\end{array}$ \\
\hline \multirow{3}{*}{1.114} & \multirow{3}{*}{0.146} & $\mathrm{X} 1$ & 0.956 & 1.047 & 0.588 & 0.05 \\
\hline & & $\mathrm{X} 2$ & 0.986 & 1.014 & 0.910 & 0.05 \\
\hline & & $\mathrm{X} 3$ & 0.947 & 1.056 & 0.531 & 0.05 \\
\hline
\end{tabular}

The researchers then conducted a classical assumption test to figure out whether residual normality, multicollinearity, and heteroscedasticity were present or not. Normality test is a critical prerequisite in regression coefficient significance testing; if the regression model is not normally distributed, then the conclusion drawn from the regression results is considered doubtful. From the normality test that was conducted, an Asymp. Sig value of 0.146 was obtained. This figure was more significant than 0.05 , meaning that the data were normally distributed.

Multicollinearity points at the presence of a strong relationship between some or all independent variables in a regression model. If the issue of multicollinearity is present, then the regression coefficient becomes uncertain. The error level would become too considerable. Too large a coefficient of determination will typically mark this, but in partial testing, the determination coefficient would become insignificant. The multicollinearity test results show that all the independent variables had tolerance values greater than 0.1 and VIF values smaller than 10. This finding means that no multicollinearity occurred in any of the independent variables. Then, from the heteroscedasticity testing with the Glejser test, sig.-values greater than 0.05 were obtained by the three independent variables. This finding means that no heteroscedasticity problem emerged in the regression model.

Table 5. Results of Multiple Linear Regression Analysis and Hypotheses Testing

\begin{tabular}{|c|c|c|c|c|c|c|}
\hline \multirow{2}{*}{\multicolumn{2}{|c|}{ Model }} & \multicolumn{2}{|c|}{ Unstandardized Coefficients } & \multicolumn{2}{|l|}{$\begin{array}{c}\text { Standardized } \\
\text { Coefficients }\end{array}$} & \multirow[b]{2}{*}{ Sig. } \\
\hline & & B & Std. Error & Beta & $\mathrm{t}$ & \\
\hline 1 & (Constant) & 16.585 & 3.566 & & 4.650 & .000 \\
\hline & Knowledge & 225 & .086 & .242 & 2.607 & .011 \\
\hline & Training & 174 & 081 & 197 & 2.157 & .033 \\
\hline & Competency & 138 & .049 & .262 & 2.805 & .006 \\
\hline & Adjusted R Square & 0.185 & & & & \\
\hline
\end{tabular}


After the data were declared valid, reliable, and meeting the classical assumption, a multiple linear regression test was then conducted. When the data in Table 5 are inputted to the general multiple linear regression equation, the following would be obtained.

$$
\mathrm{Y}=16.585+0.225 \mathrm{X} 1+0.174 \mathrm{X} 2+0.138 \mathrm{X} 3+\varepsilon
$$

The equation above can be interpreted as follows:

1. The constant $(\alpha)=16.585$. This finding suggests that if knowledge (X1), training (X2), and competency (X3) were constant, the variable employee performance $(\mathrm{Y})$ would have a value of 16.585 units. In other words, in the absence of the independent variables $(\mathrm{X} 1, \mathrm{X} 2$, and $\mathrm{X} 3$ ), the value of employee performance $(\mathrm{Y})$ would remain at 16.585 units.

2. The coefficient of the variable knowledge $(\beta 1 \mathrm{X} 1)=0.225$. This finding suggests that for every increase of one knowledge (X1) unit, employee performance would increase by 0.255 unit, under the assumption that the variables training and competency that were investigated using the regression model in this research were constant.

3. The coefficient of the variable training $(\beta 2 \mathrm{X} 2)=0.174$. This result suggests that for every increase of one training (X2) unit, employee performance (Y) would increase by 0.174 units, under the assumption that the variables knowledge and competency that were investigated using the regression model in this research were constant.

4. The coefficient of the variable competency $(\beta 3 \mathrm{X} 3)=0.138$. This finding suggests that for every increase of one competency (X2) unit, employee performance $(\mathrm{Y})$ would increase by 0.138 unit, under the assumption that the variables knowledge and training that were investigated using the regression model in this research were constant.

To figure out the partial effects of the variables knowledge, training, and competency on the variable employee performance, the researchers carried out some t-tests. The t-statistic resulted for the variable knowledge was 2.608, which was more significant than 1.97, and the sig.-level was 0.011. This finding means that the variable knowledge had a partially significant effect on the variable employee performance. Therefore, the first hypothesis saying that knowledge has a significant positive effect on the performance of field agricultural mentors/officers of the Yapen Islands Regency, was accepted. The more in-depth the knowledge of the field agricultural mentors/officers is, the higher their performance is.

This finding is in line with the research that found a significant positive relationship between the variable knowledge and the variable employee performance (Arafat et al., 2012; Kohansal et al., 2013; Nuryanti et al., 2018; Payal et al., 2019; Rizan et al., 2020). As conveyed by Palumbo et al. (2005), knowledge contributes a more significant variance in performance improvement. From the results of the descriptive analysis of the respondents' answers to the variable knowledge, it was found that the dimension with the highest mean score was the dimension interest. The outreach workers tried to follow the directions given by the team leader in performing their works and tried to be present according to the schedule that had been set. This indicates that the outreach workers' interest in knowledge was already high. The outreach workers felt that the increase in the knowledge related to work was of high importance. The frequent changes in rules urged the outreach workers to gain more knowledge to help themselves at work.

The t-statistic of the variable training was 2.157 , which was more significant than 1.97 , and the sig.-level was 0.33. This finding means that the variable training had a partially significant effect on the variable performance. This finding is in line with the research by Athar and Shah (2005), Jagero et al. (2012), Nkosi (2015), and Onyango and Wanyoike (2014), which found a significant relationship between the variable training and the variable 
performance. From the results of the descriptive analysis of the respondents' answers related to the variable training, it was found that the dimension that scored the highest mean was the dimension participant, showing that the outreach workers were passionate about participating in the training and had an understanding of what was delivered by the instructor. The more often the training program was run, the higher the field agricultural mentors/officers' performance would be. Lastly, the t-statistic of the variable competency was 2.805 , more significant than 1.97, and the sig.-level was 0.06. This result means that the variable competency, just like the previous two variables, had a partially significant effect on the variable performance. The higher the level of competency of the field agricultural mentors/officers is, the higher their performance is.

This finding is in line with the research which found a significant relationship between competency and performance (Martini et al., 2018; Sabuhari et al., 2020; Sarboini et al., 2018). From the results of the descriptive analysis of the respondents' answers, it was found that the dimension with the highest mean score was the dimension knowledge. This result means that the field agricultural mentors/officers had sufficient knowledge of the material delivered and had a mastery of the work that they did. According to Sabuhari et al. (2020), employees must have high competencies in order to be able to respond to changes in the business environment and thus improve performance. The $\mathrm{R}^{2}$ (coefficient of determination) generated was 0.185 , suggesting that the variables knowledge (X1), training (X2), and competency (X3) were able to explain the variance in the variable employee performance $(\mathrm{Y})$ at a rate of $18.5 \%$. In comparison, the remaining $81.5 \%$ was influenced by other independent variables unexplored in this research.

\section{Conclusion}

This research examined the effects of knowledge, training, and competency on the performance of field agricultural mentors/officers at the Yapen Islands Regency. From the results of the tests conducted, the following conclusions were drawn: (1) knowledge; (2); training, and (3) competency had a significant effect on the performance of field agricultural mentors/officers at the Yapen Islands Regency. The empirical findings offer some critical implications for best practices for the Yapen Islands Regency, specifically for the field

agricultural mentor/officer management. The research results suggest that the field agricultural mentors/officers need an increase in knowledge, training, and competency to improve their performance at serving the farmers and fishers of the Yapen Islands Regency. This performance improvement is expected to help the local government of the Yapen Islands Regency achieves its goals. The researchers suggest that future studies should enlarge the sample size to derive more accurate data and apply a longitudinal perspective. Besides, adding more possible variables to make a refined research work is also recommendable. Future research should be conducted when the local condition grows safely and smoothly due to the current situation, which is relatively uneasy. The process of collecting data, both primary and secondary, can run maximally. 


\section{References}

Abbas, Z. (2014). Identification of Factors and their Impact on Employees' Training and Organizational Performance in Pakistan. KASBIT Business Journal (KBJ), 7(6), 93109. https://kasbit.edu.pk/KBJVol7/KBJ May 2014 pg93-109.pdf

Abdiyanto \& Warokka, A. (2015). Priority-Driven Budgeting Policy and Regional Inequality: Does Economic Structure Transformation Really Perform as Intervening Variable? Journal of Economics Studies and Research, 2015, c1-18.

Abomaleh, A., \& Zahari, I. (2014). The impact of management commitment to service quality and customer satisfaction: A Review of Saudi Arabia public service sector. 3(1), 1-64.

Ali, A.-S., Altarawneh, M., \& Altahat, E. (2012). Effectiveness of agricultural extension activities. American Journal of Agricultural and Biological Sciences, 7(2), 194-200.

Almusaddar, A. A. S., Ramzan, S. R., \& Raju, V. (2018). the Influence of Knowledge, Satisfaction, and Motivation on Employee Performance Through Competence. International Journal of Business and General Management (IJBGM), 7(5), 21-40.

Anderson, J. R., \& Feder, G. (2007). Agricultural extension. Handbook of agricultural economics, 3, 2343-2378.

Arafat, M. Y., Warokka, A., Abdullah, H. H., \& Septian, R. R. (2012). The triple bottom line effect on emerging market companies: A test of corporate social responsibility and firm value relationship. Journal of Southeast Asian Research, 2012(2012), 1-15.

Ardiana, I., Brahmayanti, I. A., \& Subaedi, S. (2010). Kompetensi SDM UKM dan pengaruhnya terhadap kinerja UKM di Surabaya. Jurnal manajemen dan Kewirausahaan, 12(1), pp-42.

Arif, S., et al. (2019). Influence of Leadership, Organizational Culture, Work Motivation, and Job Satisfaction of Performance Principles of Senior High School in Medan City. Budapest International Research and Critics Institute-Journal (BIRCI-Journal). P. 239254.

Astuti, A. W. (2015). Pengaruh Kompetensi terhadap Kinerja Karyawan pada KSP Sendang Artha Mandiri di Kecamatan Wungu Kabupaten Madiun. EQUILIBRIUM: Jurnal Ilmiah Ekonomi dan Pembelajarannya, 3(1).

Athar, R., \& Shah, F. M. (2015). Impact of Training on Employee Performance (Banking Sector Karachi). IOSR Journal of Business and Management, Ver. I, 17(11), 23197668. https://doi.org/10.9790/487X-171115867

Buntuang, P. C. D., \& Adda, H. W. (2018). Potensi Pengembangan Sumber Daya Manusia Penyuluh Pertanian di Kabupaten Sigi. Agroland: Jurnal Ilmu-ilmu Pertanian, 25(1), 46-57.

Chen, G., Donahue, L. M., \& Klimoski, R. J. (2004). Training Undergraduates to Work in Organizational Teams. Academy of Management Learning \& Education, 3(1), 27-40. https://doi.org/10.5465/amle.2004.12436817

Cooke, F. L. (2001). Human resource strategy to improve organizational performance: A route for firms in Britain? International Journal of Management Reviews, 3(4), 321-339. https://doi.org/10.1111/1468-2370.00071

Echols, J. M., \& Shadily, H. (2007). Kamus Inggris-Indonesia. PT Gramedia.

Gujarati, D. N., \& Porter, D. C. (2009). Basic Econometrics (5th ed.). Mc Graw Hill.

Hanaysha, J. (2016). Testing the Effects of Employee Empowerment, Teamwork, and Employee Training on Employee Productivity in Higher Education Sector. International Journal of Learning \& Development, 6(1), 164-178. https://doi.org/10.5296/ijld.v6i1.9200

Harahap, R. A. M., \& Silvianita, A. (2016). Pengaruh Pelatihan Terhadap Kinerja Karyawan PT Pos Indonesia (Persero) Regional V Bandung. eProceedings of Management, 3(2). 
Jagero, N., Komba, H. V., \& Mlingi, M. N. (2012). Relationship between on the Job Training and Employees' Performance in Courier Companies in Dar es Salaam, Tanzania. International Journal of Humanities \& Social Science, 2(22), 114-120.

Kristiana, L., \& Hasan, F. (2015). Kinerja Penyuluh Pertanian Lapang Di Bpp Kecamatan Pademawu. JURNAL AGROSAINS: Karya Kreatif dan Inovatif, 2(1), 125-134.

Kulkarni, P. P. (2013). A literature review on training \& development and quality of work life. Researchers World, 4(2), 136.

Kuvaas, B., Buch, R., Gagné, M., Dysvik, A., \& Forest, J. (2016). Do you get what you pay for? Sales incentives and implications for motivation and changes in turnover intention and work effort. Motivation and Emotion, 40(5), 667-680. https://doi.org/10.1007/s11031-016-9574-6

Liao, C., Chuang, S. H., \& To, P. L. (2011). How knowledge management mediates the relationship between environment and organizational structure. Journal of Business Research, 64(7), 728-736. https://doi.org/10.1016/j.jbusres.2010.08.001

Lubell, M., Niles, M., \& Hoffman, M. (2014). Extension 3.0: Managing agricultural knowledge systems in the network age. Society \& Natural Resources, 27(10), 1089-1103.

Makawi, U., Normajatun, \& Haliq, A. (2015). Analisis Pengaruh Kompetensi Terhadap Kinerja Pegawai Dinas Perindustrian Dan Perdagangan Kota Banjarmasin. Al-Ulum Ilmu Sosial Dan Humaniora, 1(1), 16-26. http://ojs.uniskabjm.ac.id/index.php/ALSH/article/viewFile/307/290

Margono, T., \& Sugimoto, S. (2011). The barriers of the Indonesian extension workers in disseminate agricultural information to farmers. International journal of basic and applied sciences, 11(2), 4747-7302.

Martapina, A., \& Warokka, A. (2018). Decentralization and Public Expenditure: Does Special Local Autonomy Affect Regional Economic Growth? Asian International Journal of Social Sciences, 17(2), 123-138

Martini, I. A. O., Rahyuda, I. K., Sintaasih, D. K., \& Piartrini, P. S. (2018). The Influence of Competency on Employee Performance through Organizational Commitment Dimension. IOSR Journal of Business and Management (IOSR-JBM), 20(2), 29-37. https://doi.org/10.9790/487X-2002082937

Moeheriono. (2012). Pengukuran Kinerja Berbasis Kompetensi. Raja Grafindo Persada.

Nkosi, S. M. (2015). Effects of training on employee commitment, retention and performance: A case study of a Local Municipality in South Africa. European Journal of Business and Management, 7(15), 104-109. www.iiste.org

Notoatmodjo, S. (2003). Pengembangan Sumber Daya Manusia. PT. Rineka Cipta.

Notoadmojo. (2012). Promosi Kesehatan dan Ilmu Perilaku. Rineka Cipta.

Palumbo, M., Miller, C., Shalin, V., \& Steele-Johnson, D. (2005). The impact of job knowledge in the cognitive ability-performance relationship. Applied HRM Research, 10(1), 13-20.

Payal, R., Ahmed, S., \& Debnath, R. M. (2019). Impact of knowledge management on organizational performance: An application of structural equation modeling. VINE Journal of Information and Knowledge Management Systems, 49(4), 510-530. https://doi.org/10.1108/VJIKMS-07-2018-0063

Pelealu, A. E., Burdam, Y., Dasfordate, A., Djarkasi, A., Tamon, M. L., \& Artono, M. (2018). The Using of Agriculture Technology and Cultural Change in Rural Community. 1st International Conference on Social Sciences (ICSS 2018).

Pratomo, W. A., \& Warokka, A. (2013). The Linkages of Financial Liberalization and Currency Stability: What do we learn from Pre and Post Asian Financial Crisis?. Journal of Economics Studies and Research, 2013, 1.

Purnomo, S., \& Lee, Y.-H. (2010). An assessment of readiness and barriers towards ICT program implementation: Perceptions of agricultural extension officers in Indonesia. International Journal of Education and Development using ICT, 6(3), 19-36. 
Rahman, M. M., Hamid, M. K., \& Khan, M. A. M. (2015). Determinants of Bank Profitability: Empirical Evidence from Bangladesh. International Journal of Business and Management, 10(8), 135-150. https://doi.org/10.5539/ijbm.v10n8p135

Rante, A., \& Warokka, A. (2016). Leadership style, decentralisation and managerial performance: Does the management accounting system mediate the relationship?. Journal for Global Business Advancement, 9(1), 79-89.

Reber. (2010). Kamus Psikologi. Yogyakarta: Pustaka Pelajar.

Rizan, M., Warokka, A., Wibowo, A., \& Febrilia, I. (2020). Leadership Styles and Customer Loyalty: A Lesson from Emerging Southeast Asia's Airlines Industry. The Journal of Asian Finance, Economics, and Business, 7(9), 477-488.

Sabuhari, R., Sudiro, A., Irawanto, D. W., \& Rahayu, M. (2020). The effects of human resource flexibility, employee competency, organizational culture adaptation and job satisfaction on employee performance. Management Science Letters, 10(8), 17771786. https://doi.org/10.5267/j.msl.2020.1.001

Sapoetra, K. (1994). Teknologi Penyuluhan Pertanian. Bumi Aksara.

Saragih, S.L., and Ananda, R. (The Relation between the Empowerment of Teacher's Meeting and Achievement Motivation on Teacher Performances in MTsN 3 (Islamic Junior High School 3) Simalungun. Budapest International Research and Critics in Linguistics and Education (BirLE) Journal. P. 37-51.

Sultana, A., Irum, S., Abid, K., \& Nasir Mehmood. (2012). Impact of training on employee performance:A study of telecommunication sector in Pakistan. Interdisciplinary Journal of Contemporary Research in Business, March 2015, 646-661.

Tayibnapis, A. Z., Wuryaningsih, L. E., \& Gora, R. (2018). Indonesia's Efforts to Achieve Globally Competitive Human Resources. International Journal of Humanities and Social Science Invention (IJHSSI), 7(8), 1-6.

Winoto, J., \& Siregar, H. (2016). Agricultural development in Indonesia: current problems, issues, and policies. Analisis Kebijakan Pertanian, 6(1), 11-36. 